\title{
CONTRACTING OUT TEMPORARY HELP SERVICES IN GERMANY
}

\author{
ELKE J. JAHN \\ WOLFGANG OCHEL
}

CESIFO WORKING PAPER NO. 1580

CATEgORY 4: LABOUR MARKETS

NOVEMBER 2005

An electronic version of the paper may be downloaded
- from the SSRN website: $\quad$ www.SSRN.com
- from the CESifo website: www.CESifo-group.de 


\title{
CONTRACTING OUT TEMPORARY HELP SERVICES IN GERMANY
}

\begin{abstract}
Since 2003 the German Public Employment Service (PES) has been experimenting with the contracting out of various services. One of the new labour market programmes is the Personnel Service Agencies, which provide client firms with jobseekers on a temporary assignment basis and are responsible for integrating jobseekers into non-subsidised employment. By contracting out employment services, the PES seeks to exploit efficiency gains characteristic of enterprises that compete in quasi-markets. In order to integrate jobseekers as rapidly as possible, a result-oriented system of incentives has been developed. This paper describes the institutional setting and examines its appropriateness for efficient job placement services.
\end{abstract}

JEL Code: L33, J23, J41, J64.

Keywords: contracting out, quasi-markets, temporary agency work, Personnel Service Agency.

Elke J. Jahn

Federal Institute for

Employment Research (IAB)

Weddigenstr. $20-22$

90478 Nuremberg

Germany

Elke.Jahn@iab.de
Wolfgang Ochel

Ifo Institute for Economic Research

at the University of Munich

Poschingerstr. 5

81679 Munich

Germany

Ochel@ifo.de 


\section{Contracting Out Temporary Help Services in Germany}

\section{Introduction}

In the wake of the general trend towards privatisation and deregulation in the last few years, Public Employment Services (PES) have been contracted out in various OECD countries. In 1998, Australia replaced its PES with a private "Job Network" of approximately 200 firms. Placement contracts are awarded to these companies in a tendering procedure. Performance is remunerated with state premiums based on placements (Lundsgaard 2002, OECD 2001, Struyven and Steurs 2005). In 2000, the Netherlands followed Australia's example (de Koning 2004, Struyven and Steurs 2005). In the same year, the British government also began to commission private service providers with the integration of hard-to-place jobseekers (Hales et al. 2003, Hasluck et al. 2003). One of the most important innovations in Danish employment policy since 2003 is the involvement of so-called "other actors". What is new in the involvement of "other actors" in employment services is the fact that all previous "central" restrictions as to the duration, scope, target groups, average prices and types of activities of the "other actors" have been abandoned (Bredgaard et al. 2005).

The ongoing criticism of the efficiency of the PES is one of the reasons why Germany has recently started to experiment with the contracting out of employment services. The contracting out approach contrasts sharply with the way employment services have traditionally been handled in Germany. Under traditional procurement, the PES specifies the inputs and retains control rights over how the service is delivered. With the new approach the PES specifies the output, that is to say, it specifies the basic service standard, but it is the firm that decides on how to deliver the service. But in contrast to Australia and the Netherlands, which serve as prototypes for the application of the principle of market competition in the placement and reintegration of jobseekers (Struyven and Steurs 2005, OECD 2005), Germany's goal is not the privatisation of the PES. On the contrary, one seeks for alternative ways of integrating the unemployed in the labour market. In Germany, starting in 1994, temporary help services (THS) have been used for the first time as an instrument of active labour market policy. The pilot project set up with start-up financing came to an end in 1996. The goal of the programme was to facilitate the reintegration of hard-to-place jobseekers into regular employment by assigning them to client firms temporarily. Among the programme participants were long-term unemployed, those returning to the labour market after a longer absence, older people, handicapped unemployed and drug addicts. In the context of this programme, firms engaged in the provision of THS were given loans subject to repayment as well as subsidies (Vanselow and Weinkopf 2000). Microeconometric evaluation confirms the suc- 
cess of the programme. Participants showed an integration rate that was 13 percent higher than that of the control group (Almus et al. 1999, Jahn 2002).

The idea of using THS as an instrument of active labour market policy was taken up once again by the Hartz-Commission in 2002. The Hartz Commission, which was set up by the federal government, established so-called Personnel-Service-Agencies (PSA). According to Art. 37c of the Social Security Code, Third Book (SGB III), all of the 180 local employment offices are required to set up at least one PSA. The goal of the PSA is to integrate unemployed people who are not too difficult to place as quickly as possible in the labour market by assigning them temporarily to client firms; a further objective is to reduce unemployment duration. Apart from the temporary assignment, training, intensive individual counselling and close contact between the PSA and the client firms are other factors that ought to improve the reintegration chances of the programme participants.

PSA contracts were to be given with priority to commercial enterprises. Public-privatepartnerships or the local employment offices themselves could only run PSA if it had proved to be impossible to find a suitable private provider. In this sense the PES has contracted out the former public sector function to market competition. The political responsibility, however, continues to be borne by the PES, which defines the institutional design. In order to ensure that only efficient enterprises engage in assigning and placing unemployed persons, the PSA are chosen in a public tendering process. The goal of the tendering procedure was to introduce ex ante competition (Domberger and Jensen 1997). Thus conditions were created which are typical for a quasi-market (Bartlett and Le Grand 1993).

By means of contracting out labour-market services, the PES seeks to take advantage of the efficiency gains which arise when services are offered in a competitive environment. These advantages are in particular good-quality services at the lowest possible costs, the know-how of private providers with respect to assignment and placement of employees, and their knowledge of regional labour markets. But it is by no means certain that the PSA will pursue the social objectives laid down by the PES. Conflicts can arise on the one hand if the PES seeks to give priority to finding employment for difficult-to-place jobseekers; the PSA will, on the other hand, prefer easy-to-place jobseekers with better qualifications to maximize their returns; there is a risk that they will engage in "creaming" or "cherry picking". Another kind of conflict could arise if the PSA are made to bear disproportionately the risks involved in the temporary assignment of unemployed. In this case there will not be a strong motivation to engage in labour market services. Conflicts may also arise from the fact that the PSA are less interested in the placement 
of unemployed, and more in their temporary assignment. Finally, if the relationship between the contract parties is characterised by information asymmetries, then there will be a risk that the PSA will behave opportunistically. The PSA may be tempted to provide less services or a lower quality than they are contractually required to provide, in order to reduce costs. In order to avoid opportunistic behaviour of this sort, in Germany a system of result-oriented incentives has been put in place, which closely relates declining subsidies to the results produced. This system of regulation and incentives is very likely unique in the world. ${ }^{1}$

The aim of our paper is to describe the institutional framework within which the PSA operate and to analyse whether this setting is suited to integrate unemployed as quickly as possible into regular employment. Because PSA are just being put into place it is not feasible to make a final assessment of their achievements. Therefore our attention here is focused on a preliminary empirical assessment of the extent to which the conditions of quasi-markets appear to be fulfilled. Section 2 describes the quasi-market in which the PSA operate; this section also defines the criteria for evaluating the efficiency with which services are provided. In section 3, the tendering procedure is described and evaluated. Section 4 examines the referral system for the selection of unemployed persons. Sections 5 and 6 analyse whether the financial incentives are suitable to provide the PSA with sufficient motivation to assign unemployed people to jobs and in this way to integrate them quickly into the labour market. Section 7 provides a summary and conclusions.

\section{The quasi-market for PSA services}

In contracting out PSA, the PES seeks to take advantage of the efficiency gains that arise when enterprises are exposed to competition. As Domberger and Jensen $(1997,68)$ point out, a distinctive feature of contracting out is the element of ex ante competition. This means a competition for the market through competitive tendering as opposed to competition in it. As mentioned above the tendering procedure for PSA is primarily restricted to outside providers and is a precondition for access to the market. By this means conditions are created which are typical for a quasi-market. Le Grand $(2001,3)$ defines a quasi-market as a "market where independent agents compete with one another for custom from purchasers, but where, unlike in a normal market, purchasing power comes not directly from consumers but from the state". Quasi-markets differ from conventional markets in a number of ways (Le Grand and Bartlett, 1993, 10): (1)

Experience with THS as an instrument of active labour market policy was first made in the Netherlands and Sweden. However, both of these pilot projects were broken off after a very short period. 
They are "quasi" because service providers do not necessarily aim at maximizing profits, nor are they necessarily privately owned. (2) The purchasing power of the final consumers is not expressed in monetary terms; instead it is centralized in a single purchasing agency which chooses the service provider. (3) The final consumers are represented in the market by the purchasing agency instead of acting on their own account.

The quasi-market in which the PSA operate (figure 1) shows the following characteristics: based on a public tendering procedure the local employment offices choose the potential PSA. Private owned enterprises, among them temporary work agencies (TWA), educational institutions and professional placement agencies, engage in an ex ante competition for the award of a concession. Contrary to the assertion of Le Grand and Bartlett (1993), the PSA are primarily interested in maximising their returns. Although PSA can operate in the framework of a Public-Private-Partnership or may be operated by a local employment office, these organisational forms have not been realised in Germany.

Figure 1: The quasi-market for PSA services

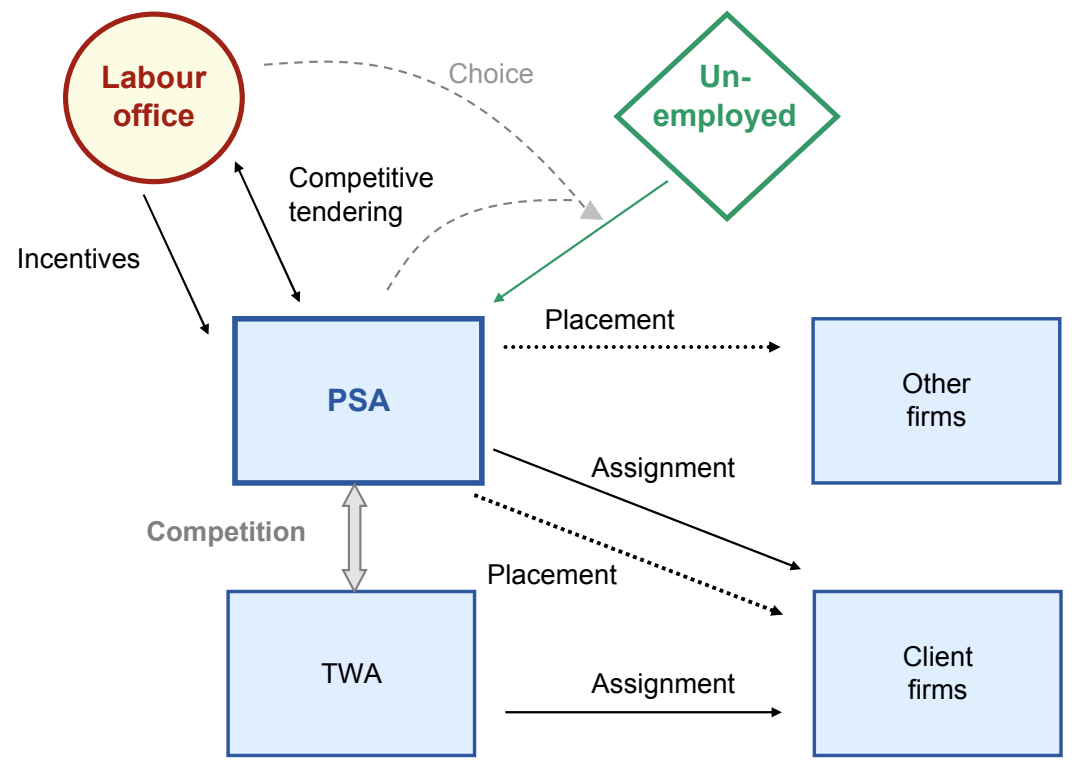

Source: Own design.

The demand for the services of the PSA comes from the PES; the unemployed have in this respect no purchasing power and do not appear as direct demanders for the assignment or placement services of the PSA. The PES designates registered jobseekers that are considered as suitable for temporary assignment or placement and refers them to the PSA; the jobseekers can not choose between different providers. Every two years, the PES decides on the number and the extent of the PSA contracts. The contract parties specify the target group, the expected integration rate and the training to be undertaken 
during periods without assignment. The providers receive declining subsidies from the PES, which are related to the period of employment within the PSA. These subsidies are made up of two components: the base subsidy and the placement premium, which are described in more detail in section 5.

The task of the PSA is to find temporary assignments at user firms for unemployed and to place them in regular employment. In contrast to professional placement services, which concentrate on the placement of unemployed and receive in return placement premiums, the PSA obtain additional revenue through their assignment activity. In this activity they compete with commercial TWA. The PSA are thus confronted with an ex ante competition in the tendering procedure and by on-going competition for potential client firms.

According to the theoretical framework of Bartlett and Le Grand (1993, 19ff.) quasimarkets can only function efficiently if the following five requirements are met:

Market Structure: The market structure has to be competitive. There should be many providers and many purchasers, each of them unable to influence the aggregate output or the price, respectively. Both, market entry and exit have to be relatively costless and otherwise unimpeded. Non-competitive providers should be driven out of the market by bankruptcy. Finally, prices should react to changes in demand and supply and should act as signals for the efficient allocation of resources. These theoretical conditions are only partially fulfilled in the quasi-market in which the PSA operate. The PES has decentralised the tendering procedure so that each local employment office can decide independently on the number of vacancies per contract and the number of (block) contracts to be advertised. In the regional labour market, the local employment office can act as a monopolist and decides on the access to the market for a limited period. The tendering procedure is broken down into three stages in which the employment offices select the most suitable bidders. Firms that have been turned down in the tendering procedure have only a new chance to engage in the service in a following up tender (see section 3). As we shall see in section 5, the pricing mechanism operates through a formula administered by the purchasing agency. Thus the prices are not formed by the interplay of demand and supply, but rather are negotiated prices.

Creaming: A second requirement of the theory of quasi-markets is that creaming among the jobseekers should be avoided. Bartlett and Le Grand $(1993,32)$ define creaming as discrimination against more expensive users. Creaming is seen when the local employment office refers to the PSA easy-to-place jobseekers, or when the PSA hire such people preferentially. In distinction to a conventional market, in the quasi-market, the local 
employment office as purchasing agency, and the PSA as service providers determine which jobseekers get a PSA job. Both parties can have an interest in focussing their activity on jobseekers that are relatively easy to assign or place: the purchasing agency has this interest since it wants to be able to show to the Federal PES that the instrument has been used successful; the service provider seeks to reduce costs or maximise profits. But only a failure to adjust the financial incentives according to the target groups will create an incentive for the PSA to engage in creaming. If contracts are tendered with a fixed number of PSA vacancies, then it will only be possible to prevent creaming by formulating clearly defined target groups which can serve as orientation in the process for referring jobseekers to the programme (see section 4).

Motivation: The third condition focuses on the motivation of the purchasing agency and the service provider. The purchasing agency must respond to the wants and needs of the unemployed and increase the choices open for their clients. The service providers should pursue economic objectives, i.e. they should primarily seek to maximise profits. If PES are privatised, it will take time for their personnel, which were accustomed to the conditions prevailing in public service, to adjust to the new conditions. Such problems of transition are not present, since potential PSA are all profit oriented and accustomed to working in a market environment. The PSA employ the jobseekers which are referred by the PES and assume all the obligations of an employer: remuneration, continued payment of wages in the event of illness and vacation payments. The PSA has also to bear theses fixed costs during periods without assignment. Hence, if they are to cover these fixed costs, they must assign their employees to client firms. A risk adverse PSA will be reluctant to conclude a contract with the PES unless the latter is prepared to assume a part of the risk sufficient to make the contract attractive to the PSA. Otherwise the PSA will simply abstain from participation in the tendering procedure (see section 5).

Information: A fourth condition for quasi-markets to operate efficiently is that the purchasing agency as well as the service provider should have access to accurate information at low cost, particularly information bearing on the cost and the quality of the service and the characteristics of the unemployed. Information asymmetries together with interest conflicts between the parties give rise to incentives that encourage opportunistic behaviour.

Amongst the various types of information asymmetries that are found in the principalagent theory, the literature on contracting out emphasises the problems arising from information asymmetries subsequent to the conclusion of a contract (e.g. Sappington 1991). There are two kinds of information asymmetries which arise between the purchasing agencies as principals and the service providers as agents: The agent's activities 
may not be observed by the principal (hidden action) or the agent may have information unavailable to the principal (hidden information) (Arrow 1985). Monitoring the agent and obtaining information both involve high costs for the principal. This is why information asymmetries give the agent space for discretionary action which he or she can use to maximise profits. If the financial incentives of the quasi-market are not compatible with the integration goals of the PES, the Federal Agency is unable to obtain its goal. The reason that information asymmetries can emerge is that the characteristics of the service are both difficult to specify prior to service delivery and difficult to identify. The same problem exists with respect to the abilities and the motivation of the jobseekers referred by the local employment offices, because it is scarcely possible to lay down their characteristics contractually. But this information is necessary for the providers to price their service appropriately.

A second source of asymmetry is related to the fact that the principal is unable to determine whether the integration obtained is due to the efforts of the PSA or whether it is simply the result of chance, perhaps abetted by a prior creaming process. Therefore information asymmetries may encourage opportunistic behaviour. It occurs where providers put in fewer resources into the provision of the service than is consistent with the terms of the contract. In our case, an example of this would be if the PSA is not providing any training or assisted placement activities to their employees in periods without assignment.

Opportunistic behaviour can be avoided if the purchaser puts in place a perfect monitoring system, which, however, entails considerable transaction costs. In order to reduce monitoring costs, the PES has developed a system of regulation and financial incentives which is partly based on the integration results obtained. Apart from the integration in the labour market, the integration speed serves as well as a measure of success. PSA which do not achieve adequate placement results run the risk of not having their fixedterm contracts renewed. Furthermore, low integration rates have financial consequences, since the placement premiums are paid depending on success (see section 6).

Transaction Costs: Relational contracts involving complex services are a typical feature of quasi-markets. In such contracts it is often very costly, or even impossible, to specify all future contingencies, and all possible adaptations to unforeseen circumstances. Therefore the contracts are incomplete. At the same time, the extent of the demand for services is ex ante uncertain. This is particularly the case when a new instrument of active labour market policy is under development. For these reasons, contract negotiations give rise to high transaction costs. On the one hand there are the costs of tendering and of drawing up, negotiating and securing contracts (,ex ante” transaction costs). On the 
other hand, there are the costs of monitoring the outcomes of contracts ("ex post" transaction costs) (Williamson 1985). Establishing a quasi-market is only successful if the improvements in efficiency are higher than the increase in transaction costs (Bartlett and Le Grand 1993, $26 \mathrm{ff}$.). To reduce the ex ante transaction costs the tendering procedure involves three stages. This implies a saving for both the commissioning body and the potential providers as is described in the next section. Moreover, because contracts are not taken out for each individual client but for groups (block contracts), time and effort spent in negotiation and therefore transaction costs are reduced (Jahn and Windsheimer 2004a, 3).

\section{The tendering procedure}

A contract is awarded to the PSA after a public tendering procedure. The goal of this ex ante competition is to ensure that only those firms operate as a PSA whose qualifications meet the standards set by the PES. The tendering procedure involves three stages. The pre-selection of agencies begins with a public invitation to tender by the local employment office. The bidding documents lay down the terms and conditions of the PSA contract. Among other things, the number and the characteristics of the jobseekers that are to be referred to the PSA are set out. The goal is to make it easier for interested firms to decide to participate and to facilitate bidders' cost calculations. Based on the description in the call to submit tenders, interested parties may announce their interest to participate in the competition. They must prove their reliability. Furthermore, they must also show evidence of their experience as a commercial or non-profit TWA, a professional placing agency, or some other former involvement in active labour market policies. Having carried out successfully such an activity in the last twelve months is sufficient proof. Finally, they must provide evidence of their capability. In general, this requirement is fulfilled if a tendering firm can show commercial experience, which provides a basis for supposing that the organisational ability will permit the firm to operate successfully as a PSA. From the list of applicants the local employment office selects suitable candidates, who are then given the opportunity to submit a bid.

In the second stage the bidder must specify a price. The amount of base subsidies and placement premiums which the PSA can expect to receive will depend on this price (see section 5). Furthermore, the tender must provide a detailed proposal on how the PSA will be run. The concept must include details concerning the personnel and structure of the planned PSA, the collective agreement to be used, the strategy for acquiring commissions from client firms, the expected extent of assignment periods and training activities foreseen during periods in which employees are without assignment, as well as 
the achievable integration rate, which can be used as a measure of success when the local employment office will come to decide on the renewal of the contract. The bids are ranked according to the price and quality. Price and quality of the offers are evaluated together. Between April 2003 and April 2004, the tender price was given a weight of 60 percent, the quality of the offer based on the PSA concept 40 percent. The bankruptcy of the largest PSA-firm with 10,000 PSA-employees in February 2004, has made it advisable to place more weight on the quality of the bids. Now, the tender price is given a weight of 40 percent and the quality of the offer 60 percent. The PSA concept is evaluated on a scale between one and ten, with a variety of criteria being used. The score emerges from the evaluation of the concept presented. Nevertheless the grading of the quality of the PSA concept is based on the subjective assessments of the responsible employees in the local employment office. Thus the bidders do not know in detail what standards are used to evaluate the individual parts of their PSA concept.

In a third stage, after the evaluation has been completed, the local employment office enters into negotiations with up to five bidders who have submitted the most economical offers. Finally a fixed-term contract, which is usually limited to 24 months, is signed with one of the bidding companies. An extension for further 24 months is possible.

This tendering procedure has advantages and disadvantages. First, the decentralised tendering procedure makes it possible for the local employment office to determine the number of contracts and vacancies according to conditions in the regional labour market. This makes the task of keeping in touch with the needs of the unemployed easier. On the other hand, the relationship between both sides will be too intimate, so it will be difficult to maintain the distance that a market process requires. This is all the more the case since many local employment offices have been cooperating for quite some time with the tendering firms. Second, a restricted invitation to tender increases the success chances of the bidders so that they take greater care in preparing their bids, which in turn increases the quality. Furthermore, restricted tendering involves cost savings for the firms as well as for the local employment offices, as they have fewer bids to prepare or assess, respectively. On the other hand, by setting up a qualifying competition in advance, the number of bids and thus the variety of bids is restricted. The renewal option means that newcomers have only a reduced chance of participating.

In the tendering procedure, only those competitors which have already provided successfully services in close proximity to the market will be given a contract. In this way, the PES ensures that tendering firms are really able to fulfil their contractual obligations. Then too, in the course of the tendering procedure, the potential PSA has documented the services that it proposes to provide. 
Apart from the choice of suitable enterprises, a further task of the public tendering procedure is to determine the amount of subsidies that the PSA should receive. The subsidies have to respond to four requirements: in the first place they must ensure that the PSA do not suffer losses so that they have an incentive to take part in the tendering procedure. Second, the subsidies have got to be sufficient to cover the periods when an employee is not on assignment and be sufficient to finance the training which is required for those times. Third, the subsidy must allow a reduction of the assignment fees in order to increase demand for employees who are difficult to place. And finally, the subsidies must satisfy the "principle of cost-effectiveness" of the public sector. Crowding out effects and deadweight losses should be avoided. Quantifying the subsidies that just fulfil these conditions represents a very difficult, indeed scarcely solvable, problem for the local employment offices. In contrast to the PSA, employment offices have only partial knowledge of the market for THS; hence they have difficulty in estimating the receipts of the PSA on this head. One of the functions of the tendering procedure is to determine what the marginal costs are, which makes it possible to infer the "efficient" level of subsidies under competitive conditions.

\section{Recruiting the unemployed without creaming?}

The success of the contracting out is multi-dimensional. Dimensions are the choice of the most productive PSA, the number of PSA-jobs created, the integration rate and, finally, the avoidance of creaming. Up to the end of March 2004, the Federal PES instructed the local employment offices to create at least one PSA job for a hundred unemployed persons. The number of vacancies per contract and the target groups could be decided by the local employment office itself taking into account the situation prevailing in the regional labour market. Since April 2004, the local employment offices can fix the number of PSA contracts and the number of jobs in each contract at their discretion, subject to their budget constraints. The law does, however, lay down that each local employment office must have at least one PSA under contract. By February 2005, 1,235 PSA contracts had been concluded; of these 414 contracts were no longer in force, so that at that time 821 PSA contracts were still in force. A PSA provides on an average for 43 vacancies (figure 2). Nearly a half of the PSA contracts provide for between 40 and 60 vacancies. Contracts with less than 20 vacancies make up only 2.5 percent of all contracts; such contracts are typically concluded for target groups which are difficult to place. Contracts providing for 60 vacancies are concluded for long-term unemployed and for low-skilled unemployed that are considered easy to place. The PSA offers the jobseekers a fixed-term contract for nine to twelve months. During this period the PSA assume all the contractual obligations of an employer. The employer can dis- 
miss the employee at any time during the probation period of six month, afterwards with good cause.

Figure 2: PSA contracts by number of vacancies, February 2005

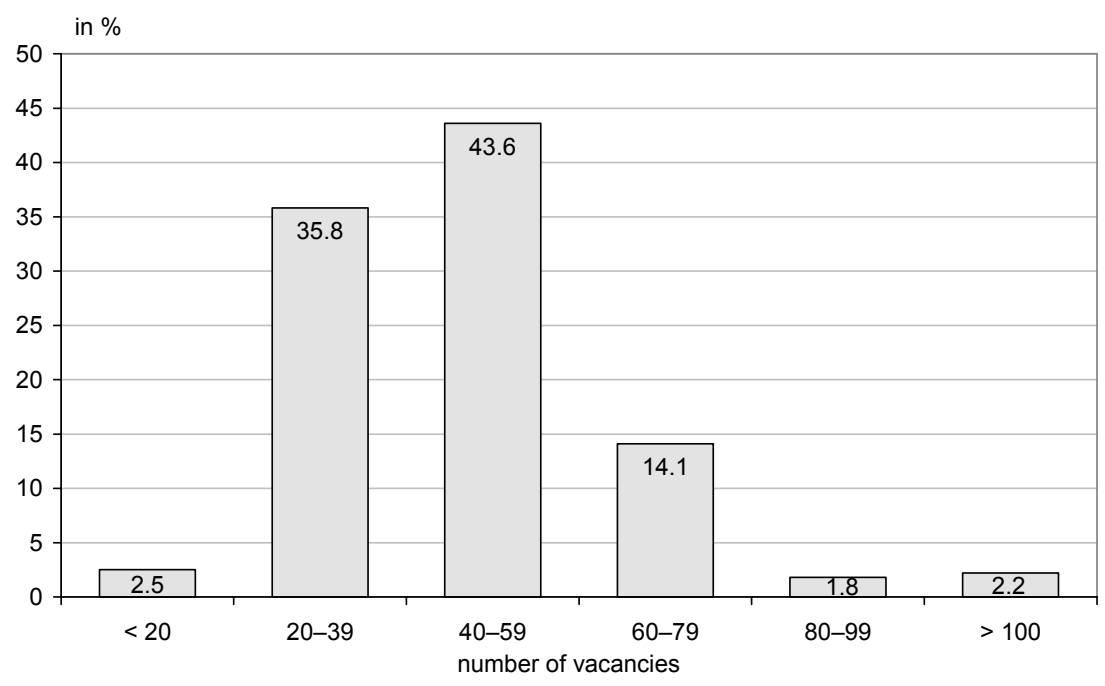

Source: Bundesagentur für Arbeit, own calculations.

Up to April 2004, the PSA had to fill their vacancies within three months. As figure 3 shows, only a few PSA were able to meet this requirement. In October 2003, just 60 percent of the vacancies had been filled. The reason for this is that PSA initially seek to acquire requests for workers from client firms before they accept referrals of unemployed. In reaction to this, the PES has changed the terms. Since April 2004, the PSA are contractually obliged to fill 25 percent of the vacancies during the first month, and this mark applies to the following months as well. After four months, the contractually agreed number of vacancies must be filled, or at a minimum 90 percent of them (Jahn 2004, 5). Figure 3 shows that despite this requirement, the share of filled vacancies comes to about 75 percent: it has not as yet proved to be possible to enforce full compliance with the conditions of the contracts in this respect. The reason is that the PES has scarcely any sanctions that it can impose for non-compliance. Although it can terminate a contract with a notice period of three month, the local employment offices have been reluctant to apply this drastic measure. One reason for this reluctance is that a new tender is costly; another reason is that there is an element of legal uncertainty if a fixedterm contract is terminated prematurely. 
Figure 3: Stock, inflow and share of filled vacancies

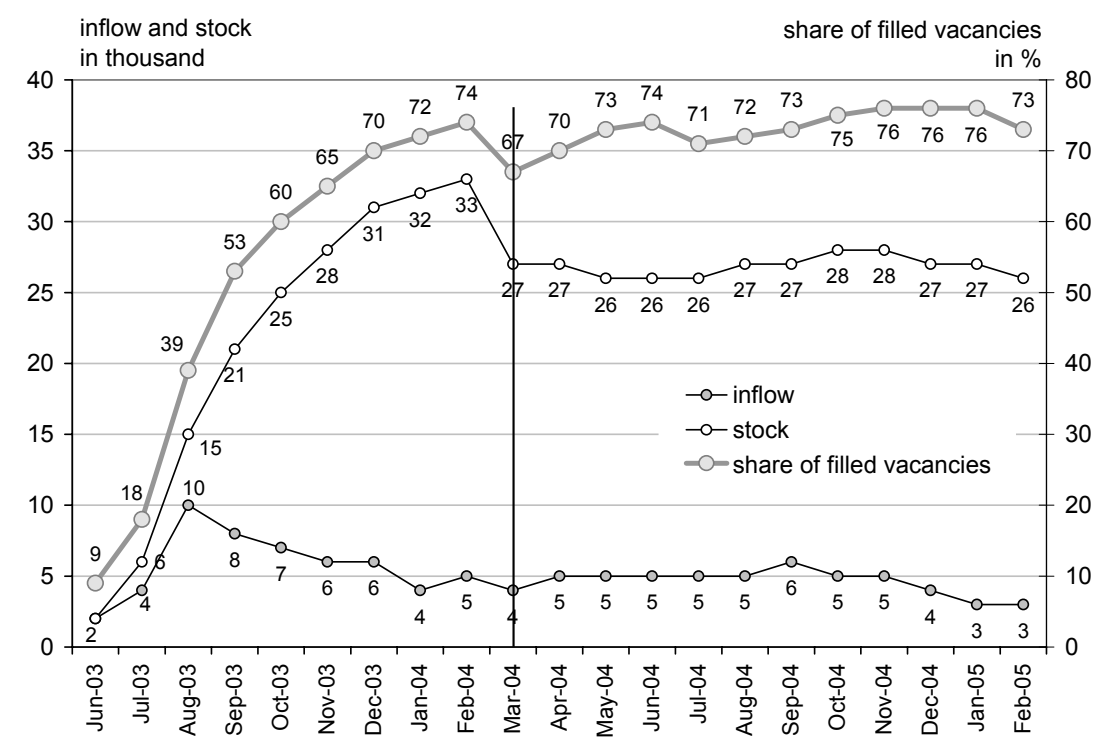

Source: Bundesagentur für Arbeit, own calculations.

Figure 3 shows that the largest inflow into the PSA were registered in August 2003 (9,600 entries) and in September 2003 (8,400 entries). There are good reasons for supposing that the introductory phase was essentially completed by October 2003. Up to February 2004, the stock of PSA-employees climbed steadily, reaching a peak of 33,000 in that month. In that month the largest provider, with 200 contracts and 10,000 vacancies became insolvent and as a result there was a marked dip in the number of PSAworkers. By the following month, March 2004, they were down to 27,000. As a reaction to the rather modest reintegration rates (see section 6), many contracts that had terminated were not renewed, so that in February 2005 only 25,700 formerly unemployed were still employed by PSA.

If providers and local employment offices concentrate on those jobseekers that are easiest to place or to assign to a user firm, then creaming is taking place. This occurs if the contracts do not define the target groups unambiguously. The preferred target group of the PES are jobseekers who cannot be quickly placed by the PES, but who have only low level impediments to placement and thus are potentially employable and suitable for temporary assignment. Furthermore, they have to be eligible to receive unemployment benefits. The target group includes young people, jobseekers without vocational qualification, long-term unemployed, and unemployed who represent a risk of becoming long-term unemployed, unemployed with health problems and older people. In the tendering procedure, the local employment office specifies the target groups with respect to occupational and personal characteristics; such a specification might be in terms of young people under 25 with vocational training in a technical area. The local employ- 
ment offices tend to define target groups that are as homogenous as possible (Sinus 2003).

The local employment offices make a first selection of the unemployed they want to refer to the PSA. The PSA, however, can refuse to accept a jobseeker. It is obvious that the PSA prefer unemployed for whom it is easy to find a temporary assignment or are easy to place. Thus the selection process is subject to the control of the service provider. Furthermore, the PSA prefer heterogeneous target groups. They argue that broadly defined groups make it easier to respond to the needs of their clients. However, there are objections to acceding to this wish (Jahn 2004). First of all, there is no compelling reason why PSA ought to restrict their effort to unemployed that have been referred by the PES; there is no reason why they should not attend to specific demands for temporary agency workers (TAW) by recruiting employees in the regular labour market. The intention behind establishing PSA was not to subsidise the entire market for THS. Second, it should be taken into account that in defining heterogeneous target groups one is making it easier for the PSA to engage in cherry picking (Ochel 2004). Especially large TWA, when they are operating as a PSA, apply the same standards when deciding whether or not to accept the unemployed selected by the PES as they do when they recruit a TAW in the free market.

In order to prevent creaming, the local employment offices have to ensure that they only refer jobseekers which belong to the target groups defined in the contract. Experience in Germany shows that PSA are able to enforce their ideas with respect to the personnel structure of the PSA-employees. In interviews carried out between June 2003 and October 2004, the local employment offices reported that only 22 percent of the jobseekers who had been pre-selected by them were accepted by the PSA. The PSA not only select their employees in the context of the referral procedure, but also subsequently, when they dismiss their employees. 31.6 percent of employees leaving the PSA between June 2003 and February 2005 were dismissed for misbehaviour or economic reasons.

A further indication that creaming is taking place can be derived from a comparison of the socio-economic characteristics of PSA-employees as compared to employees working for TWA. ${ }^{2}$ Table 1 shows that the employees in PSA differ very little from TAW. Older employees (those 50 years or older) have less chance to be employed by a PSA than by a TWA ( 9 percent versus 11 percent). Furthermore, participants in the PSA programme are more likely to have had vocational training then their counterparts in TWA

\footnotetext{
2 In comparing the socio-economic characteristics of PSA-employees with non-subsidised TAW one must bear in mind that the data are taken from different statistical sources. In particular, the indices referring to vocational training and length of unemployment are defined differently.
} 
(61 percent versus 53 percent). Only 27 percent of PSA-employees were without vocational training; for the TAW the figure was 30 percent. And finally, only 29 percent of PSA-employees had been previously unemployed for between six and twelve months; only 14 percent were classified as long-term unemployed. Thus long-term unemployed persons had scarcely a better chance of finding employment in the PSA programme than in a non-subsidised TWA (this question is dealt with in more detail in Jahn and Windsheimer 2004b). Women, however, are more likely to be employed by a PSA than by a non-subsidised TWA. Unemployed with health problems (12 percent) are surprisingly often found in a PSA. Comparable information for TAW is not available. In interpreting table 1 it must be borne in mind that a jobseeker may have more than one obstacle to placement: an unemployed person for example may have health problems, lack vocational training and be over 50 years of age. Table 1 sheds no light on whether an accumulation of impediments to placement is found more often amongst PSA-employees than amongst TAW.

Table 1: Individual characteristics of TAW and PSA-employees in Germany, in \%

\begin{tabular}{|l|c|c|}
\hline \multicolumn{1}{|c|}{ Characteristics } & PSA $^{\text {a) }}$ & TAW $^{\text {b) }}$ \\
\hline Gender (female) & 33.3 & 27.2 \\
Job seeker with health problems & 11.7 & n.a. \\
Age in years & & \\
$<20$ & 3.9 & 2.1 \\
$20-24$ & 33.0 & 20.9 \\
$25-34$ & 23.8 & 30.9 \\
$35-49$ & 30.4 & 35.1 \\
$>50$ & 8.9 & 11.1 \\
Vocational training (VT) & 27.2 & 30.2 \\
Without VT & 9.6 & - \\
With VT (outside firm) & 60.5 & 52.4 \\
With VT (in firm) & 1.7 & 2.8 \\
University degree & 1.0 & 14.6 \\
Unknown & & \\
Unemployment duration in months & 45.8 & $50.8^{\text {c) }}$ \\
Less than 6 & 28.8 & $11.2^{\text {c) }}$ \\
6-12 & 14.4 & - \\
Long-term unemployed & 3.9 & - \\
Unknown & 7.1 & \\
Registered as jobseekers & & \\
\hline a) Inflow in PSA, April 2003 to January 2004, Source: Jahn (2004), & \\
b) Stock of TAW, age 15-65; Source: BA, Beschäftigtenstatistik, as of 30 June 2004, \\
c) Source: BA, Arbeitnehmerüberlassungsstatistik, as of 30 June 2004, own calculations. \\
\hline \multicolumn{2}{|}{} \\
\hline
\end{tabular}




\section{Financial incentives, balancing of risk and assignment activity}

In order to attain its integration target, the PES must not only choose suitable firms to run the PSA and refer suitable jobseekers, but it also subsidises every employee of the PSA. The PSA receive a base subsidy for every person hired; for every placement in employment subject to social security contributions they receive a placement premium. The amount of both of these subsidies depends on the offer price negotiated before the contract is concluded; it varies according to target group and the conditions in the regional labour market. Table 2 provides information on the amount of the base subsidy and the placement premium in relation to offer prices.

Table 2: Amount of base subsidy and placement premium as a \% of offer prices

\begin{tabular}{|c|c|c|}
\hline $\begin{array}{c}\text { Employment duration } \\
\text { in months }\end{array}$ & Base subsidy & $\begin{array}{c}\text { Placement } \\
\text { premium }\end{array}$ \\
\hline $1-3$ & 100 & 200 \\
$4-6$ & 75 & 150 \\
$7-9$ & 50 & 100 \\
$>10$ & 0 & 100 \\
\hline
\end{tabular}

Source: Own compilation.

The base subsidy is paid per PSA-employee and per month; the placement premium depends on the successful placement of the jobseeker. Since it is better to place a jobseeker in a sustainable rather than a temporary job, the placement premium is broken down into two equal parts. The first instalment is due at the beginning of any period of regular employment that is programmed to last at least three months. The second instalment is paid when the PSA can prove that the jobseeker is still employed after six month. In the PSA contracts that went into effect up to February 2005, 38 percent of the contracts had an offer price of between 1,100 and 1,300 $€$; in a fourth of the contracts the offer price fell between 900 and 1,100 $€ .17$ percent of the contracts provide for an offer price of between 700 and $900 €$; in 11 percent, an offer price between 1,300 and $1,500 €$ has been agreed upon. The average offer price was $1,084 €$ (figure 4).

In paying a base subsidy, the PES covers a part of the risk of the PSA. Their risk arises because they hire jobseekers with slight impediments to placement for a period limited to nine months. In comparison to non-subsidised TWA, the combination of narrowly defined target groups and fixed-term employment gives rise to longer periods in which the unemployed persons are not on assignments. The base subsidy is supposed to cover not only these costs, but also the costs involved in training and coaching (Jahn and Windsheimer 2004a, 3). The idea behind the base subsidy is thus to guarantee unem- 
ployed that they will be employed for at least nine months. Instable employment which is confined to a temporary assignment should be avoided.

Figure 4: Offer price in PSA contracts, February 2005

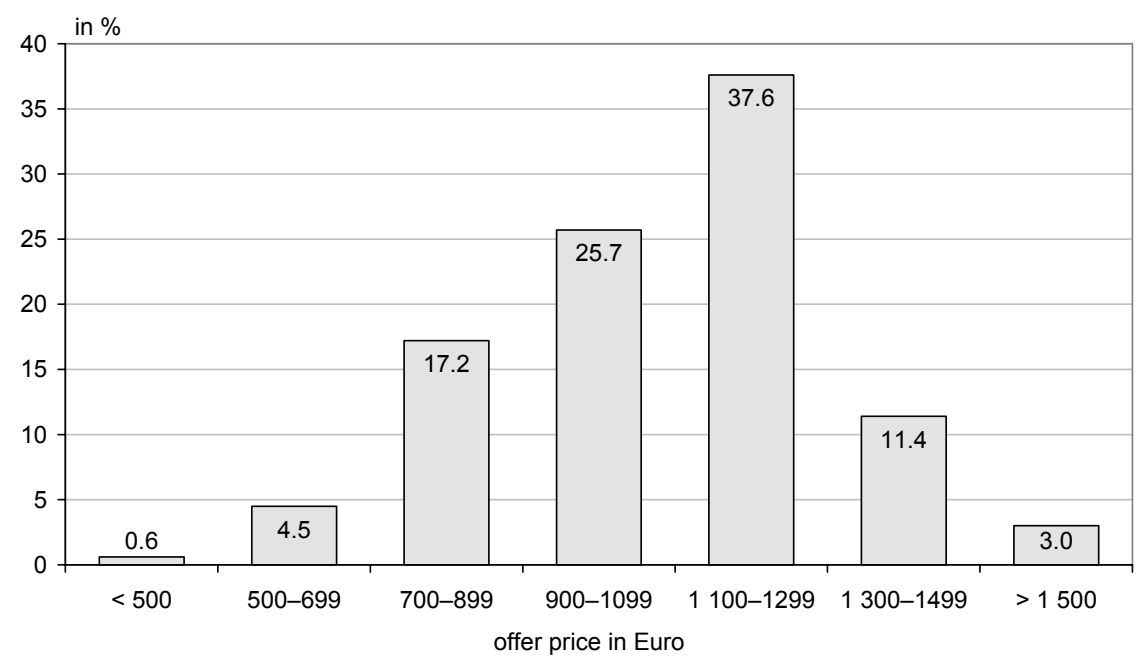

Source: Bundesagentur für Arbeit, own calculations.

The extent to which the PES subsidies a PSA-employee is examined in table 3. The amount of subsidy depends on the employment duration of the PSA-employee. In table 3 , four cases are distinguished: periods of employment of three, six, nine and twelve months. These periods have been chosen, since the subsidy formula varies at intervals of a quarter year. The estimates are based on an hourly wage of ten $€$. This corresponds to hourly wages in wage group four, including wage supplements in the main collective agreement for temporary agency work in 2005. The employer's share of social security contributions comes to 20.6 percent of the gross wage. The personnel costs related to placement efforts, coaching and training amount to 25 percent of the gross wage (Bertelsmann Stiftung et al. 2002, 30). In addition, it is assumed that the PSA incur fixed costs of $600 €$ when they hire an unemployed person. The calculations are based on an offer price of $1,100 €$, which corresponds approximately to the average offer price. We further assume that every vacancy can be filled as soon as it is created; in view of the 5.2 million unemployed that confronted 34,000 PSA vacancies in February 2005 , this assumption seems reasonable. In addition, the calculations take into account that between April 2003 and February 2005, more than 81,000 employees have left the PSA programme (table 5). Of these, 26,000, or 32 percent have found employment. Approximately 25 percent of the PSA-employees were placed in a job by a PSA or were taken over by a client firm where they were working on temporary assignment. Only in such cases are the PSA entitled to a placement premium. 
Table 3: Degree of subvention for a PSA-employee per year

\begin{tabular}{|l|r|r|r|r|}
\hline \multirow{2}{*}{} & \multicolumn{4}{|c|}{ Employment duration of a } \\
\cline { 2 - 5 } & twelve & \multicolumn{1}{|c|}{ nine } & \multicolumn{1}{c|}{ six } & \multicolumn{1}{c|}{ three } \\
\hline Total payments, of which $(€)$ & 26,808 & 27,008 & 27,408 & 28,608 \\
Gross wages & 18,000 & 18,000 & 18,000 & 18,000 \\
Social security contributions & 3,708 & 3,708 & 3,708 & 3,708 \\
Personnel costs & 4,500 & 4,500 & 4,500 & 4,500 \\
Fixed hiring costs & 600 & 800 & 1,200 & 2,400 \\
Total subsidies ,of which & 7,700 & 10,267 & 12,375 & 15,400 \\
Base subsidy & 7,425 & 9,900 & 11,550 & 13,200 \\
PP (with integration rate 25\%) & 275 & 367 & 825 & 2,200 \\
Coverage & & & & 46 \\
Not including PP (in \%) & 28 & 37 & 42 & 46 \\
Including PP (in \%) & 29 & 38 & 45 & 54 \\
\hline PP: placement premium & \multicolumn{5}{|c}{} \\
\hline
\end{tabular}

Source: Own calculations.

The amount of the subsidy depends on both the employment duration in a PSA and the probability of reintegration. If the PSA-employees are employed for three months, than the PSA can fill a vacancy four times a year and in this case the PSA will receive a monthly base subsidy equal to 100 percent of the offer price. If a PSA employs two jobseekers, each for six months, then the monthly base subsidy will amount to 100 percent of the offer price for six months and for a further six months to 75 percent of the offer price. Table 3 shows that if a PSA-employee is employed for twelve months, then the base subsidy will cover 28 percent of costs; for nine months the coverage is 37 percent; with six months, the coverage is 42 percent; and for three months, the base subsidy will cover 46 percent of the costs. The PSA can count on these subsidies without having successfully integrated a single unemployed person. If the PSA succeeds in placing the jobseeker, then they are entitled to a placement premium. Assuming an integration rate of 25 percent, the share of costs covered by the base subsidy and the placement premium comes in the four cases examined to $29,38,45$ and 54 percent respectively. The calculations set forth in table 3 show that the local employment offices of the PES bear a part of the PSA' risk, but that the PSA cannot cover all their costs through subsidies.

The subsidies allow the PSA to reduce the fees they charge for employees temporary assigned to client firms; this increases the attractiveness of these employees. This can be seen when one compares the calculation with the fees of a non-subsidised TWA. Such firms charge a fee for temporary assignment amounting to approximately two and a half times the gross remuneration of their employees. This margin is calculated so as to 
cover the personnel costs incurred when the employees are not on temporary assignment, which arise owing to illness, annual leave, and lack of commissions. This downtime typically amounts to approximately 25 percent of the regular working year (Kvasnicka 2004, 20). ${ }^{3}$ With time on assignment amounting to 75 percent, and an average duration of employment (in a TWA or a PSA) of three months, a TWA will have a yearly profit per employee of $5,142 €$. For a PSA receiving subsidies, the profit will work out to 20,542 € yearly. Assuming constant time on assignment, the PSA could reduce its assignment fee to $13.60 €$ an hour, before its profits would fall below that of a TWA (table 4).

In February 2005, the average duration of assignment of PSA-employees was 49 percent of the working schedule. This low share as compared to assignments of traditional TWA was the result of the requirement to fill their posts quickly, even when there is no prospect of assignment for new employees. Another factor is that the PSA are required to train their employees when they are not on assignment. Traditional TWA, on the other hand, can synchronise new hirings with the beginning of new assignments. Nevertheless, there are grounds for supposing that the PSA could increase assignments by reducing their fees. The bottom line of table 4 shows that assuming constant time on assignment, the PSA could reduce their fees to $14.98 €$ without fear of incurring losses. Lower assignment fees can be justified with human capital arguments. Productivity deficits are often attributed to persons participating in active labour market programmes; their performance is thought to be below average, or it is thought that they present themselves badly or that they have occupational qualifications for which there is little market demand (Jahn and Windsheimer 2004b, 5). As a result, unemployed jobseekers have difficulty finding employment at the prevailing wage rate. Only if the fees of the PSA are below the prevailing market price, are user firms willing to accept such people for temporary assignment. But very few PSA differentiate in their pricing between PSA-employees and their traditional employees hired on the open market. The scarce practice of demanding lower fees for the PSA-employees has been vehemently criticised by the trade unions, which consider this as a form of wage dumping. The reluctance to scale down the fees may be due to the fact that many PSA are run by traditional TWA. If the PSA gives a rebate for PSA-employees, although their productivity is comparable to that of the TWA's other employees, then there is a risk that the fees charged for the TWA's non-subsidised employees will be subject to downward pres-

3 There is no systematic information about downtime in TWA. However, the case study conducted by Kvasnicka (2004) provides information on this problem. If one adds the working days in which the employees were not out on assignment to the days worked, the days on paid leave, including sick leave, then one has the share of days when the employees were being paid, but were not on assignment. 
sure. And finally, the reason for this reluctance could also lie in an unwillingness on the part of the PSA to pass on the subsidy to its clients. Assuming that the PSA-employee is on assignment 49 percent of the time, and assuming a fee for temporary assignment of $25 €$, the profits of the PSA per employee will amount to $8,842 €$ yearly (table 4 ).

Table 4: Assignment fees and duration of assignment

\begin{tabular}{|c|c|c|c|c|c|}
\hline $\begin{array}{c}\text { Duration of } \\
\text { assignment }\end{array}$ & Fee / hour & $\begin{array}{c}\text { Revenue from } \\
\text { temporary as- } \\
\text { signments }\end{array}$ & $\begin{array}{l}\text { Cost } / \\
\text { employee }\end{array}$ & Subsidies $^{\text {a)b })}$ & Profit or loss \\
$\%$ & $€$ & $€$ & $€$ & $€$ & $€$ \\
\hline 75 & 25.00 & 33,750 & 28,608 & 0 & 5,142 \\
75 & 25.00 & 33,750 & 28,608 & 15,400 & 20,542 \\
75 & 13.60 & 18,350 & 28,608 & 15,400 & 5,142 \\
49 & 25.00 & 22,050 & 28,608 & 0 & $-6,558$ \\
49 & 25.00 & 22,050 & 28,608 & 15,400 & 8,842 \\
49 & 14.98 & 13,208 & 28,608 & 15,400 & 0 \\
\hline
\end{tabular}

Source: Own calculations.

\section{Placement incentives}

Monitoring the activities of PSA involves high transaction costs. To avoid moral hazard PSA are obliged to provide regular information to the PES concerning their activities. Furthermore, the PES has put in place a system of incentives that is based on the results obtained. The objective behind the declining payment structure is to ensure that the PSA reintegrate their employees as quick as possible into the regular labour market. The payment of the placement premium in two instalments should avoid that the new job of the PSA-employees is of short duration. The answer to the question, to what extent the financial incentives conform to these objectives, depends above all on whether the employees leaving the programme can be replaced quickly. If it is not possible to refill vacancies immediately, then the PSA will have no interest on rapid placement. The reason for this is that a PSA can also make profits on its assignment activity.

If the provider succeeds in filling a vacancy in a short time, then it will be able to fill a post several times during the term of the contract. Successful PSA thus have the possibility of repeatedly obtaining a placement premium. Since the base subsidy is also declining, a period of employment of three months always results in the maximum subsidy per unemployed person. 
Figure 5: Total and marginal subsidy per PSA vacancy

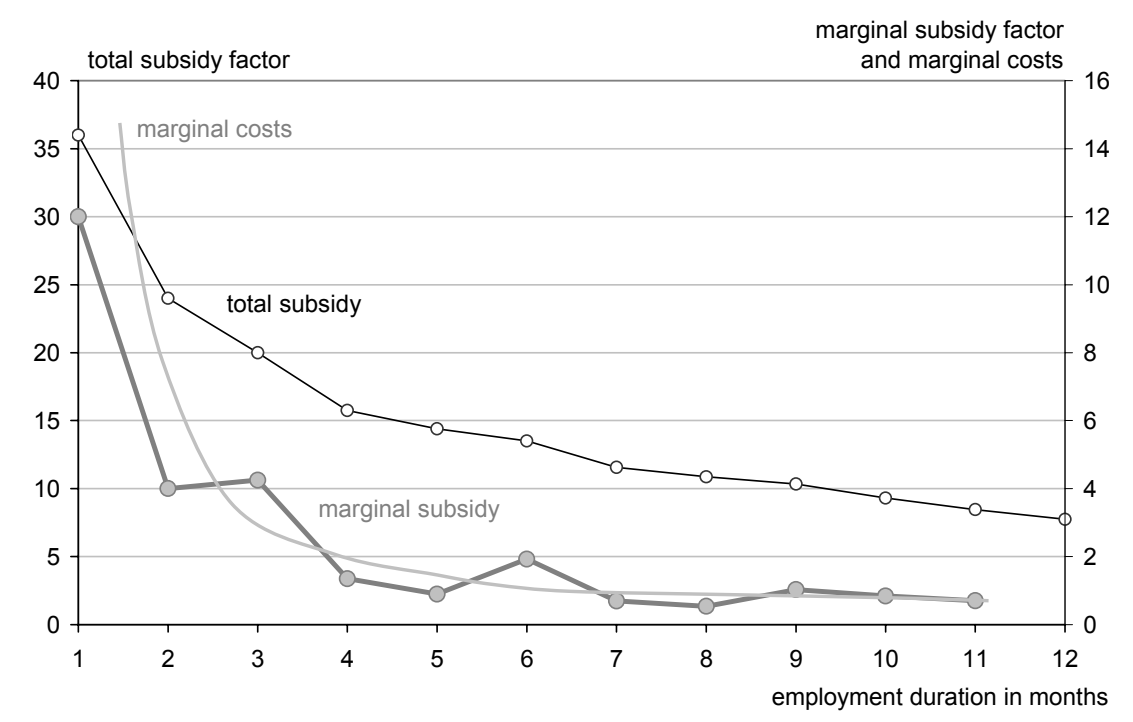

Source: Own calculations.

The incentive structure is shown in figure 5. The employment duration of a PSA-employee is depicted on the abscissa. The corresponding subsidy factor, expressed as a multiple of the offer price, the marginal subsidy factor as well as the marginal costs are shown on the ordinates. For the sake of simplicity we assume that each PSA-employee is successfully placed, that vacancies can be refilled immediately and that the PSA contract is open-ended. Figure 5 shows that the amount of the subsidy per PSA vacancy varies directly with the number of placements and increases with shorter employment duration. For an employment period of six months, the total subsidy comes to 13.5 times the offer price for an entire year. If the duration of employment is three months, the subsidy comes to 20 times the offer price; a duration of one month results in a total subsidy factor of 36 . Given an average offer price of $1,100 €$, the PSA can count on revenue of between 14,850 and $39,600 €$.

The dark line in figure 5 marks the marginal subsidy. The marginal return to rapid placement is highest during the first three months. The marginal return decreases with increasing employment duration. That the marginal return function is not monotonically decreasing follows from the declining discrete payment structure. From the tenth month on, the base subsidy is no longer paid, and the placement premium remains constant. The marginal return is nevertheless positive, because the PSA can fill the vacancy immediately with a new employee, for whom new subsidies will be paid pro rata. At first sight the payment structure represents an incentive for the PSA to place their employees as rapidly as possible. It seems that this incentive remains in force even if the PSA is not able to place every employee successfully (figure 6). If the placement premium increases in relation to the base subsidy (the premium structure being given), then the 
incentives for the PSA to place their employees as quickly as possible become stronger. But on the other hand, in that case there are fewer resources available to compensate PSA for the risks they bear.

Figure 6: Amount of subsidy as a function of the integration rate

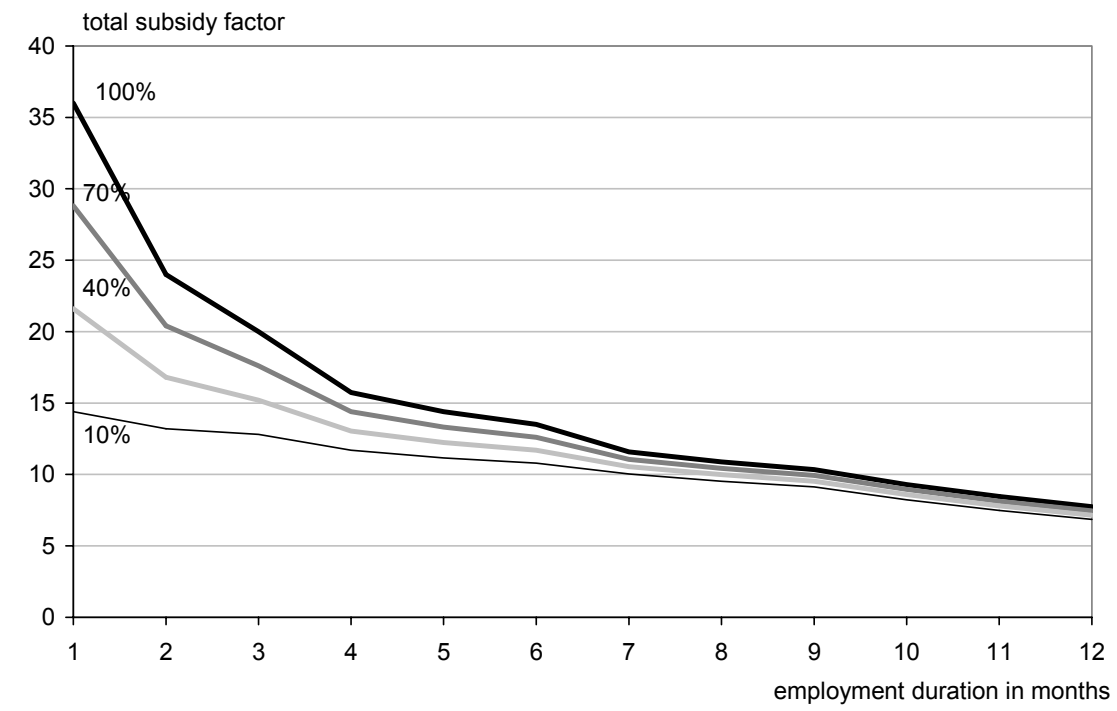

Source: Own calculations.

In order to determine the profit maximising employment duration, in addition to the marginal return the marginal costs associated with different turnover rates must be taken into account. First, the turnover increases if the PSA intensifies its contacts with potential employers. Second, the PSA can increase the attractiveness of its employees by providing them with targeted training and coaching. In both cases, the marginal costs of its services increase. Increasing turnover rates also lead to increasing hiring costs, since hiring a new employee always involves recruiting costs. The PSA will only be interested in speeding up placement as long as the marginal return is higher than the marginal costs. Figure 5 assumes a convex marginal cost function. It shows that as a result of the declining discrete payment structure, an unique profit maximising employment duration does not exist. In February 2005, the average employment duration in a PSA was approximately six months. There are two possible interpretations for this result: First, the financial incentives are not sufficient to bring about a rapid integration of PSA-employees in the labour market; second, the point in time of the placement is not a parameter of managerial action (in opposition to the assumption underlying figure 5). The low labour demand in Germany and its weak growth support the second interpretation.

Table 5 provides a further indication of the low absorption capacity of the labour market since the start of the programme. The integration rates are broken down by East and 
West, in order to take into account the difficult labour market situation in East Germany. As table 5 shows, between June 2003 and February 2005, the average integration rate came to 32 percent. But between the Länder of the former Federal Republic and the new Länder there are considerable differences. The integration rate in the West was 36 percent; in East Germany, on the other hand, non-subsidised employment could be found for only 25 percent of PSA-employees. Between June 2003 and February 2005, direct placement in client firms amounted to 11 percent in the West, in East Germany the figure was only 5 percent. The low placement in client firms was, however, compensated by the placement of PSA workers in other firms. 16 percent of exiting employees found regular employment subject to social insurance contributions in this manner. Thus, the PSA tended to function more as professional placement agencies than as TWA. Quite a few PSA-employees (8 percent) found work through their own initiative. In interpreting these figures, it should be borne in mind that the integration rates presented in table 5 do not shed any light on the causal treatment effect which is estimated in microeconometric evaluations. It is conceivable that the unemployed might have found regular (i.e. non-subsidised) employment without the placement efforts made on their behalf. Furthermore selection biases will tend to bias downwards the impact of the programme.

Table 5: Integration rate for PSA-employees

\begin{tabular}{|l|r|r|r|}
\hline \multicolumn{4}{|c|}{ Exits into employment / all exits June 2003 - February 2005, in \% } \\
\hline & East & West & Germany \\
\hline Employed, total & 24.5 & 36.2 & 32.2 \\
Client firm & 5.1 & 10.9 & 8.9 \\
Placed by PSA & 14.4 & 16.6 & 15.8 \\
Employee's own initiative & 5.0 & 8.8 & 7.5 \\
Self-employed & 0.3 & 0.4 & 0.4 \\
All exits & 27,431 & 53,721 & 81,152 \\
\hline
\end{tabular}

Source: Bundesagentur für Arbeit, own calculations.

Can the reintegration rates documented in table 5 be considered to represent a success? In order to answer this question it is instructive to compare them with the integration rates obtained by non-subsidised TWA. The survey carried out in 2000 for the International Association of Temporary Work Agencies showed that 29 percent of German TAW were able to find regular employment within a year (CIETT 2000). ${ }^{4}$ Rudolf and

\footnotetext{
4 The transition rate defined in the CIETT study is not comparable methodologically with the definition of the integration rate by the PES. It must also be pointed out that only a small number of employees were included in the CIETT survey. The survey was conducted in during a period of cyclical upturn, which made integration easier.
} 
Schröder (1997) estimate an integration rate of 31 percent in the 1980s. Taking into consideration the fact that amongst the PSA-employees are probably quite a number with one or more impediments to placement, the integration rate of PSA-employees is quite respectable. The higher integration rate achieved for PSA-employees as compared to employees in TWA indicates that the system of incentives and regulation is having a positive effect in helping to get unemployed back into a job. The integration effects were, however, higher than those achieved in the pilot projects in the 1990s mentioned previously. The PES does not consider the integration rate that has been achieved to be satisfactory. When the programme was conceived, an integration rate of 50 percent was assumed; this is the reason for the restraint that has been exercised since the middle of 2004 with respect to putting new contracts up for tender. Integration rates that fall short of expectations are also related - as already mentioned - to the insufficient labour demand in Germany. In a recession, enterprises are reluctant to hire new employees. Particularly in Germany, employers react to fluctuations in demand for their products by first taking advantage of the possibilities of internal flexibility such as overtime work and working time accounts for their employees.

\section{Conclusions}

Since April 2003 the German PES has used temporary agency work as an instrument of active labour market policy. The goal of contracting out is to take advantage of the efficiency gains which arise when enterprises are exposed to competition in quasi-markets. The task of the PSA is to find temporary assignments for the unemployed referred to their care and ultimately to integrate their employees into non-subsidised employment. The PES gives priority to rapid integration. The literature dealing with contracting out formulates five conditions that must be fulfilled if quasi-markets are to function efficiently.

The local employment offices invite publicly tenders for PSA contracts. In this way, an ex ante competition for the market is created. The decentralised tendering procedure has the advantage of taking into account the local labour market situation and the needs of the jobseeker. In order to lower the transaction costs involved in choosing suitable bidders, the tendering procedure comprises three stages. However, the unemployed, who are the ultimate users of the services, can not choose between different providers; they are referred to providers by the local employment offices. Therefore the ultimate users can not influence the price and quality of the service, which is negotiated in advance by the employment agency and the PSA. Once a firm has been chosen to receive a contract in the tendering procedure, it no longer faces competition for the contract. However, the PSA is faced with competition from other TWA with respect to the acquisition of com- 
missions from clients. The PSA can not avoid this competition, since the subsidies only partly cover their costs. As strange as it may seem, the insolvencies suffered by many PSA document the fact that this market mechanism is indeed working.

In order to avoid creaming, the process for referring jobseekers to programmes should be outside the control of the providers. The empirical evaluation shows, however, that a creaming process nevertheless has taken place. It seems to be the case that the PSA have succeeded in imposing their personnel preferences on the local employment offices at the stage of selecting PSA-employees. The high proportion of dismissed PSA-employees is another indication that the PSA is engaged in the selection of unemployed. This selection is the result of the lack of possibilities for sanctioning such behaviour; apart from the possibility of not renewing a contract, the local employment offices have no other enforcement procedures. Furthermore, the local employment offices were subject to extreme pressure to produce favourable results. Therefore they could scarcely oppose the wishes of the PSA.

Providers ought to be motivated by financial considerations. The purpose of the subsidies provided is to cover a part of the risk. For the PSA are obliged to hire jobseekers with impediments to placement, even though there are no commissions from clients. As shown in section 5 the amount of coverage depends on the duration of employment. The service of the PSA has two dimensions: its quality and quantity. The share of employees on assignment and the amount of training provided during periods of non-assignment can be taken as measures for the quality of the services provided by a PSA. It is an open question whether the subsidies have influenced the quality of the services; the share of temporary assignments achieved by the PSA is much lower than the share prevailing among traditional TWA. Investigations based on sampling have also shown that some PSA do not provide any training. The integration rate is one measure of the quantity of the service and is below what was expected. This may be an indication that especially the declining base subsidy, which is not directly related to success, is not sufficient to promote rapid integration.

Information asymmetries are often a central theme in the literature on contracting out. To avoid problems with respect to lack of information the PES uses in addition to a monitoring system an incentive compatible payment system which depends heavily on the success of the PSA. The integration rate represents a simple quantification of the services provided. The subsidy which decreases with the employment duration in the PSA is designed to provide an incentive for the PSA to integrate the unemployed as quickly as possible in the regular labour market. In order to prevent short-term placements, the placement premium is paid in two instalments, and the second instalment 
only falls due when the employee is still employed after six months. In this way, the PES receives information on the quality of the placement. Most PSA-employees are placed in jobs directly, although this activity is a new field for firms principally engaged in the provision of THS. Because of these direct placements the integration rates achieved by PSA compared to those of traditional TWA were somewhat higher. Empirical evaluation seems to confirm that especially the placement premiums are a suitable instrument for the promotion of rapid integration via direct placements.

In order to limit transaction costs the PES puts block contracts up for tender. By defining the target groups in the contract, negotiations concerning the jobseekers referred to the PSA can be avoided. But since the PSA can refuse jobseekers that have been selected by the PES, high transaction costs nevertheless arise when the process of designating PSA-employees goes into a second or third round.

Although most of the conditions for a functioning quasi-market are fulfilled, nevertheless the PSA were subject to vehement criticism from the outset. The PSA were considered as the core idea of the Hartz proposals and as such they stood under great pressure to produce favourable results. The programme was introduced during a period when the market for TAW was stagnating or even in slight decline. The insolvency of the largest provider caused an enormous image problem. But the continued criticism of the instrument is surprising in the light of the fact that up till now there has been no systematic evaluation of the programme. The modification of the conditions of contract after just one year does, to be sure, make such an evaluation difficult. In the autumn of 2005 new modifications of the institutional setting are to be expected. The tendering procedure will be centralised and carried out by the Federal PES. Furthermore, the base subsidy will be paid as a flat rate which is much lower than at present and independent of the employment duration and the composition of the target group. And finally, the placement premium is to be increased and is to be made the subject of negotiations within the tendering procedure. From a theoretical point of view it is doubtful that this reform will enhance the efficiency of the programme. Furthermore continual changes in the institutional settings bear the risk of reducing the political acceptance of what was at its inception a good idea. 


\section{References}

Almus, M., J. Egeln, M. Lechner, F. Pfeiffer and H. Spengler (1999), Wirkungen gemeinnütziger Arbeitnehmerüberlassungen in Rheinland-Pfalz, Beiträge zur Arbeitsmarkt- und Berufsforschung Bd. 225, Nuremberg.

Arrow, K.J. (1985), “The Economics of Agency", in J.W. Pratt and R.J. Zeckhauser, eds., Principals and Agents: The Structure of Business, Boston, 37-51.

Bartlett, W. and J. Le Grand (1993), "The Theory of Quasi-Markets", in J. Le Grand and W. Bartlett, eds., Quasi-Markets and Social Policy, London, 13-34.

Bertelsmann Stiftung, Bundesanstalt für Arbeit, McKinsey Company, eds.(2002), Die Personal-Service-Agentur (PSA), Konzeption und Diskussion eines neuen arbeitsmarktpolitischen Instruments, Gütersloh.

Bredgaard, T., F. Larsen and L.R. Möller (2005), Contracting-out the Public Employment Service in Denmark: A Quasi-market Analysis, Paper presented to the Transitions and Risk - New Directions in Social Policy Conference, Centre for Public Policy, University of Melbourne, 23-25 Feb. 2005, Center for Labour Market Research at Aalborg University.

Bundesagentur für Arbeit (BA), Statistik-Datenzentrum, Nuremberg.

CIETT (2000), Orchestrating the Evolution of Private Employment Agencies Towards a Stronger Society, Brussels.

De Koning, J. (2004), The Reform of the Dutch Public Employment Service, Erasmus University, SEOR, Rotterdam.

Domberger, S. and P. Jensen (1997), "Contracting out by the Public Sector: Theory, Evidence, Prospects”, Oxford Review of Economic Policy 13 (4), 67-78.

Hales, J., R. Taylor, W. Mandy and M. Miller (2003), Evaluation of Employment Zones: Report on a Cohort Survey of Long-term Unemployed People in the Zones and a Matched Set of Comparison Areas, National Centre for Social Research, November 2003.

Hasluck, C., P. Elias and A. E. Green (2003), The Wider Labour Market Impacts of Employment Zones, DWP Research Report W175, November 2003.

Jahn, E.J. (2002), „Leiharbeit auf dem Prüfstand: Brückenschlag mit PSA kann gelingen", IAB-Materialien 4, Nuremberg, 7-9.

Jahn, E. (2004), „Personal-Service-Agenturen - Design und Implementation“, in B. Vogel, ed., Leiharbeit. Aktuelle sozialwissenschaftliche Befunde, Hamburg, 61-84.

Jahn, E. and A. Windsheimer (2004a), „Personal-Service-Agenturen - in der Fläche schon präsent", IAB-Kurzbericht 01/2004, Nuremberg.

Jahn, E. and A. Windsheimer (2004b), „Personal-Service-Agenturen - erste Erfolge zeichnen sich ab“, IAB-Kurzbericht 02/2004, Nuremberg.

Kvasnicka, M. (2004), Inside the Black Box of Temporary Help Employment, Humboldt University Berlin, Berlin, mimeo. 
Le Grand, J. and W. Bartlett (1993), "Introduction", in J. Le Grand and W. Bartlett, eds., Quasi-Markets and Social Policy, London, 1-12.

Le Grand, J. (2001), The Quasi-Market Experiments in Public Service Delivery: Did They Work?, Paper for Presentation at Pontignano Conference, 6-8 April 2001 (http://www.-econ-pol.unisi.it/welfare/legrand.pdf).

Lundsgaard, J. (2002), "Competition and Efficiency in Publicly Funded Services", OECD Economic Studies 35 (2), 79-128.

Ochel W. (2004), "Competitive Tendering and Contracting of Temporary Work Agencies in Germany", CESifo DICE Report 2 (2), 69-74.

OECD (2001), Innovations in Labour Market Policies - the Australian Way, Paris.

OECD (2005), Public Employment Services: Managing Performance, OECD Employment Outlook, Chapter 5, Paris.

Rudolph, H. and E. Schröder (1997), „Arbeitnehmerüberlassung: Trend und Einsatzlogik", Mitteilungen aus der Arbeitsmarkt- und Berufsforschung 1, 102-126.

Struyven, L. and G. Steurs (2005), "Design and Redesign of a Quasi-market for the Reintegration of Jobseekers: Empirical Evidence from Australia and the Netherlands", Journal of European Social Policy 15, 211-229.

Sappington, D.E.M. (1991), "Incentives in Principal-Agent Relationships", Journal of Economic Perspectives 5 (2), 45-66.

Sinus (2003), Zwischenbericht zur Implementation von PSA, Nürnberg, mimeo.

Vanselow, A. und C. Weinkopf (2000), Wiedereingliederung von Arbeitslosen durch sozialverträgliche Arbeitnehmerüberlassung: Ergebnisse der fachlichen Begleitung von START Zeitarbeit NRW, Düsseldorf.

Williamson, O. (1985), The Economic Institutions of Capitalism, New York. 


\section{CESifo Working Paper Series}

(for full list see www.cesifo-group.de)

1517 Kira Boerner and Silke Uebelmesser, Migration and the Welfare State: The Economic Power of the Non-Voter?, August 2005

1518 Gabriela Schütz, Heinrich W. Ursprung and Ludger Wößmann, Education Policy and Equality of Opportunity, August 2005

1519 David S. Evans and Michael A. Salinger, Curing Sinus Headaches and Tying Law: An Empirical Analysis of Bundling Decongestants and Pain Relievers, August 2005

1520 Michel Beine, Paul De Grauwe and Marianna Grimaldi, The Impact of FX Central Bank Intervention in a Noise Trading Framework, August 2005

1521 Volker Meier and Matthias Wrede, Pension, Fertility, and Education, August 2005

1522 Saku Aura and Thomas Davidoff, Optimal Commodity Taxation when Land and Structures must be Taxed at the Same Rate, August 2005

1523 Andreas Haufler and Søren Bo Nielsen, Merger Policy to Promote 'Global Players'? A Simple Model, August 2005

1524 Frederick van der Ploeg, The Making of Cultural Policy: A European Perspective, August 2005

1525 Alexander Kemnitz, Can Immigrant Employment Alleviate the Demographic Burden? The Role of Union Centralization, August 2005

1526 Baoline Chen and Peter A. Zadrozny, Estimated U.S. Manufacturing Production Capital and Technology Based on an Estimated Dynamic Economic Model, August 2005

1527 Marcel Gérard, Multijurisdictional Firms and Governments' Strategies under Alternative Tax Designs, August 2005

1528 Joerg Breitscheidel and Hans Gersbach, Self-Financing Environmental Mechanisms, August 2005

1529 Giorgio Fazio, Ronald MacDonald and Jacques Mélitz, Trade Costs, Trade Balances and Current Accounts: An Application of Gravity to Multilateral Trade, August 2005

1530 Thomas Christiaans, Thomas Eichner and Ruediger Pethig, A Micro-Level 'Consumer Approach’ to Species Population Dynamics, August 2005

1531 Samuel Hanson, M. Hashem Pesaran and Til Schuermann, Firm Heterogeneity and Credit Risk Diversification, August 2005 
1532 Mark Mink and Jakob de Haan, Has the Stability and Growth Pact Impeded Political Budget Cycles in the European Union?, September 2005

1533 Roberta Colavecchio, Declan Curran and Michael Funke, Drifting Together or Falling Apart? The Empirics of Regional Economic Growth in Post-Unification Germany, September 2005

1534 Kai A. Konrad and Stergios Skaperdas, Succession Rules and Leadership Rents, September 2005

1535 Robert Dur and Amihai Glazer, The Desire for Impact, September 2005

1536 Wolfgang Buchholz and Wolfgang Peters, Justifying the Lindahl Solution as an Outcome of Fair Cooperation, September 2005

1537 Pieter A. Gautier, Coen N. Teulings and Aico van Vuuren, On-the-Job Search and Sorting, September 2005

1538 Leif Danziger, Output Effects of Inflation with Fixed Price- and Quantity-Adjustment Costs, September 2005

1539 Gerhard Glomm, Juergen Jung, Changmin Lee and Chung Tran, Public Pensions and Capital Accumulation: The Case of Brazil, September 2005

1540 Yvonne Adema, Lex Meijdam and Harrie A. A. Verbon, The International Spillover Effects of Pension Reform, September 2005

1541 Richard Disney, Household Saving Rates and the Design of Social Security Programmes: Evidence from a Country Panel, September 2005

1542 David Dorn and Alfonso Sousa-Poza, Early Retirement: Free Choice or Forced Decision?, September 2005

1543 Clara Graziano and Annalisa Luporini, Ownership Concentration, Monitoring and Optimal Board Structure, September 2005

1544 Panu Poutvaara, Social Security Incentives, Human Capital Investment and Mobility of Labor, September 2005

1545 Kjell Erik Lommerud, Frode Meland and Odd Rune Straume, Can Deunionization Lead to International Outsourcing?, September 2005

1546 Robert Inklaar, Richard Jong-A-Pin and Jakob de Haan, Trade and Business Cycle Synchronization in OECD Countries: A Re-examination, September 2005

1547 Randall K. Filer and Marjorie Honig, Endogenous Pensions and Retirement Behavior, September 2005

1548 M. Hashem Pesaran, Til Schuermann and Bjoern-Jakob Treutler, Global Business Cycles and Credit Risk, September 2005 
1549 Ruediger Pethig, Nonlinear Production, Abatement, Pollution and Materials Balance Reconsidered, September 2005

1550 Antonis Adam and Thomas Moutos, Turkish Delight for Some, Cold Turkey for Others?: The Effects of the EU-Turkey Customs Union, September 2005

1551 Peter Birch Sørensen, Dual Income Taxation: Why and how?, September 2005

1552 Kurt R. Brekke, Robert Nuscheler and Odd Rune Straume, Gatekeeping in Health Care, September 2005

1553 Maarten Bosker, Steven Brakman, Harry Garretsen and Marc Schramm, Looking for Multiple Equilibria when Geography Matters: German City Growth and the WWII Shock, September 2005

1554 Paul W. J. de Bijl, Structural Separation and Access in Telecommunications Markets, September 2005

1555 Ueli Grob and Stefan C. Wolter, Demographic Change and Public Education Spending: A Conflict between Young and Old?, October 2005

1556 Alberto Alesina and Guido Tabellini, Why is Fiscal Policy often Procyclical?, October 2005

1557 Piotr Wdowinski, Financial Markets and Economic Growth in Poland: Simulations with an Econometric Model, October 2005

1558 Peter Egger, Mario Larch, Michael Pfaffermayr and Janette Walde, Small Sample Properties of Maximum Likelihood Versus Generalized Method of Moments Based Tests for Spatially Autocorrelated Errors, October 2005

1559 Marie-Laure Breuillé and Robert J. Gary-Bobo, Sharing Budgetary Austerity under Free Mobility and Asymmetric Information: An Optimal Regulation Approach to Fiscal Federalism, October 2005

1560 Robert Dur and Amihai Glazer, Subsidizing Enjoyable Education, October 2005

1561 Carlo Altavilla and Paul De Grauwe, Non-Linearities in the Relation between the Exchange Rate and its Fundamentals, October 2005

1562 Josef Falkinger and Volker Grossmann, Distribution of Natural Resources, Entrepreneurship, and Economic Development: Growth Dynamics with Two Elites, October 2005

$1563 \mathrm{Yu}-\mathrm{Fu}$ Chen and Michael Funke, Product Market Competition, Investment and Employment-Abundant versus Job-Poor Growth: A Real Options Perspective, October 2005

1564 Kai A. Konrad and Dan Kovenock, Equilibrium and Efficiency in the Tug-of-War, October 2005 
1565 Joerg Breitung and M. Hashem Pesaran, Unit Roots and Cointegration in Panels, October 2005

1566 Steven Brakman, Harry Garretsen and Marc Schramm, Putting New Economic Geography to the Test: Free-ness of Trade and Agglomeration in the EU Regions, October 2005

1567 Robert Haveman, Karen Holden, Barbara Wolfe and Andrei Romanov, Assessing the Maintenance of Savings Sufficiency Over the First Decade of Retirement, October 2005

1568 Hans Fehr and Christian Habermann, Risk Sharing and Efficiency Implications of Progressive Pension Arrangements, October 2005

1569 Jovan Žamac, Pension Design when Fertility Fluctuates: The Role of Capital Mobility and Education Financing, October 2005

1570 Piotr Wdowinski and Aneta Zglinska-Pietrzak, The Warsaw Stock Exchange Index WIG: Modelling and Forecasting, October 2005

1571 J. Ignacio Conde-Ruiz, Vincenzo Galasso and Paola Profeta, Early Retirement and Social Security: A Long Term Perspective, October 2005

1572 Johannes Binswanger, Risk Management of Pension Systems from the Perspective of Loss Aversion, October 2005

1573 Geir B. Asheim, Wolfgang Buchholz, John M. Hartwick, Tapan Mitra and Cees Withagen, Constant Savings Rates and Quasi-Arithmetic Population Growth under Exhaustible Resource Constraints, October 2005

1574 Christian Hagist, Norbert Klusen, Andreas Plate and Bernd Raffelhueschen, Social Health Insurance - the Major Driver of Unsustainable Fiscal Policy?, October 2005

1575 Roland Hodler and Kurt Schmidheiny, How Fiscal Decentralization Flattens Progressive Taxes, October 2005

1576 George W. Evans, Seppo Honkapohja and Noah Williams, Generalized Stochastic Gradient Learning, October 2005

1577 Torben M. Andersen, Social Security and Longevity, October 2005

1578 Kai A. Konrad and Stergios Skaperdas, The Market for Protection and the Origin of the State, October 2005

1579 Jan K. Brueckner and Stuart S. Rosenthal, Gentrification and Neighborhood Housing Cycles: Will America's Future Downtowns be Rich?, October 2005

1580 Elke J. Jahn and Wolfgang Ochel, Contracting Out Temporary Help Services in Germany, November 2005 